JPPMS, Vol. 4, No. 2, 2020

Jurnal Penelitian Pendidikan Matematika dan Sains

http://journal.unesa.ac.id/index.php/jppms/

\title{
Pengaruh Motivasi dan Minat Belajar Siswa Terhadap Prestasi Belajar Matematika Selama Study at Home
}

\author{
Oleh: \\ Novenia Hizkia Wulansari ${ }^{1}$,Janet Trineke Manoy ${ }^{2}$ \\ ${ }^{1,2}$ Jurusan Matematika FMIPA Universitas Negeri Surabaya \\ 1noveniawulansari16030174036@mhs.unesa.ac.id \\ 2janetmanoy@unesa.ac.id
}

\begin{abstract}
Abstrak - Baru - baru ini dunia dihebohkan dengan wabah virus corona yang berasal dari Wuhan, Cina. Virus corona ini sangat berbahaya karena sejauh ini belum ditemukan obat atau vaksin. Virus ini sangat cepat penyebarannya karena menyerang saluran pernafasan manusia jadi dapat menyebar melalui udara. WHO telah menetapkan virus ini sebagai penyakit pandemik karena telah menyerang berbagai negara di dunia, termasuk Indonesia. Beberapa bidang di Indonesia juga ikut terdampak akibat virus ini, tak terkecuali di bidang pendidikan. Proses pembelajaran di sekolah harus terhenti dan siswa harus belajar di rumah (study at home), hal ini akan berpengaruh pada motivasi dan minat belajar siswa. Artikel ini bertujuan untuk melihat pengaruh motivasi dan minat belajar siswa terhadap prestasi belajar siswa selama study at home. Metode yang diterapkan yaitu metode penelitian kuantitatif dengan jenis penelitian expost facto. Sampel penelitian ini yaitu siswa kelas XI MIA 4 SMAN 16 Surabaya yang berjumlah 29 siswa. Data diperoleh melalui angket yang kemudian data dianalisis secara deskriptif. Hasil uji hipotesis, yaitu 1) Mengetahui pengaruh motivasi belajar terhadap prestasi belajar siswa selama study at home, 2) Mengetahui pengaruh minat belajar terhadap prestasi belajar siswa selama study at home, 3) Mengatahui pengaruh motivasi dan minat belajar siswa terhadap prestasi belajar siswa selama study at home.

Kata kunci: Motivasi belajar, minat belajar, prestasi belajar, study at home
\end{abstract}

Abstract - Recently the world was shocked by the corona virus outbreak which originated in Wuhan, China. This corona virus is very dangerous because so far no drug or vaccine has been found. This virus spreads very quickly because it attacks the human respiratory tract so it can spread through the air. WHO has designated this virus as an pandemic disease because it has attacked various countries in the world, including Indonesia. Several fields in Indonesia have also been affected by this virus, including in the field of education. The learning process at school must stop and students must study at home, this will affect students' motivation and interest in learning. This article aims to examine the effect of student motivation and interest in student learning achievement during study at home. The method applied is quantitative research methods with ex post facto research. The sample of this research is the students of class XI MIA 4 SMAN 16 Surabaya, amounting to 29 students. The data were obtained through a questionnaire, then the data were analyzed descriptively. The results of hypothesis testing are 1) Knowing the effect of learning motivation on student achievement during study at home, 2) Knowing the effect of interest in learning on student achievement during study at home, 3) Determining the effect of motivation and interest in student learning on student achievement during study at home.

Keywords: Interest In Learning Motivation, Achievement, Learning Math, study at home

\section{Pendahuluan}

Wabah Corona Virus Disease (COVID-19) muncul pertama kali di Wuhan, China pada bulan desember 2019. Awalnya virus ini dianggap sebagai virus normal yang mudah penyembuhannya, ternyata salah dugaan. Virus ini menyebar dengan sangat mudah dan cepat. Menurut WHO cara penularan COVID-19 bisa melalui percikan - percikan dari hidung atau mulut yang keluar saat orang yang terinfeksi batuk, bersin, ataupun berbicara. Gejala - gejala orang terkena COVID-19 pun beragam, paling umum seperti demam, batuk kering, dan rasa lelah.

Banyak korban berjatuhan akibat meluasnya virus ini di Wuhan. Tidak hanya di Wuhan, virus ini cepat menyebar ke provinsi lain di China. COVID-19 sangat luar biasa, dalam 3 bulan mampu merenggut ribuan nyawa. Hingga saat ini virus ini telah menyebar sangat cepat di berbagai belahan dunia, seperti Korea Selatan, Italia, Iran, 
Inggris, Jepang, Amerika Serikat, Indonesia, dan negara lainnya.

Pemerintah Indonesia langsung mengambil tindakan yang tegas akibat adanya wabah COVID19. Salah satunya yaitu larangan berkumpul dan beraktivitas di luar rumah, untuk itu saat ini semua aktivitas yang biasanya dikerjakan di luar rumah sekarang dikerjakan dirumah, bila terpaksa berkegiatan di luar rumah diharapkan tidak melakukan kontak fisik dengan masyarakat lainnya dan harus jaga jarak minimal 1,5 meter.

Meskipun COVID-19 sudah masuk ke Indonesia, pemerintah Indonesia tidak ingin semua bidang berhenti, termasuk bidang pendidikan. Kegiatan Belajar Mengajar (KBM) tetap terlaksana, tetapi KBM yang biasanya dilaksanakan di sekolah sekarang harus dilaksanakan di rumah untuk meminimalisir virus ini menyebar.

Sampai saat ini proses KBM tetap dilaksanakan sampai waktu yang belum ditentukan. Menurut GTK DIKDAS (2020), UNESCO mengatakan lebih dari $91 \%$ populasi siswa dunia telah dipengaruhi oleh penutupan sekolah. Kurniadi (2020) juga melihat dari hasil survey KPAI mengungkapkan bahwa 139 (17,5\%) dari 800 anak di Indonesia terpapar corona, $80 \%$ orang tua siswa menghendaki tetap belajar dari rumah.

Menurut Rizqulloh (2020) Pembelajaran Jarak Jauh (e-learning) merupakan suatu pendekatan pembelajaran yang pada pelaksanaannya tidak bertatap muka langsung di kelas, sehingga semua proses pembelajaran akan berbeda dengan yang di sekolah. Noesgaard, S. S., \& Ørngreen, R. (2015) mengatakan ada beberapa alat yang bisa digunakan e-learning seperti email, blog, wikipedia, eportofolio, animasi, tautan video hingga jejaring sosial seperti Twitter, Facebook, Youtube, Google Classroom, Edmodo, dan sebagainya. Karena pembelajaran jarak jauh merupakan hal baru tentunya akan menimbulkan beberapa kendala seperti jaringan internet buruk, komitmen dari orang tua yang tidak menentu, siswa yang sulit belajar dengan cara ini, timbul kesalahpahaman antara siswa dan guru, dan ketidakpahaman IPTEK (Ni'mah, 2016). Hal ini juga dapat mempengaruhi prestasi belajar siswa kedepannya.

Ada beberapa faktor agar prestasi belajar siswa tetap maksimal. Menurut Slameto (2010) ada faktor internal dan eksternal. Faktor internal meliputi kecerdasan, sikap, bakat, minat, motivasi siswa, dan lingkungan sebagai faktor eksternal. Guru sebagai pengelola pembelajaran mesti mampu mengatur dan mengeksplorasi potensi siswa guna meningkatkan prestasi belajarnya.
Menurut penelitian Kurniawan dan Wutsqa (2014), menunjukkan sesungguhnya motivasi belajar berdampak pada prestasi belajar. Sedangkan menurut penelitian lain oleh Siagian (2015) minat belajar juga mempengaruhi prestasi belajar. Sejalan dengan dua peneliti di atas Heriyati (2017) mengungkapkan bila motivasi dan minat belajar mempengaruhi prestasi belajar. Berdasarkan penelitian di atas, berikut definisi dari beberapa ahli mengenai motivasi belajar, minat belajar, dan pestasi belajar.

Menurut Sofyan dan Uno (2012) motivasi adalah keinginan seseorang untuk mengubah perilaku diri agar lebih baik. Badaruddin (2015) mengatakan gerakan psikologis dari orang yang melakukan tindakan untuk mencapai tujuan belajar disebut motivasi belajar. Menurut Heriyati (2017) motivasi belajar adalah sikap siswa memperoleh pengetahuan, pemahaman, keterampilan setelah mengikuti kegiatan belajar berdasarkan kecenderungan sikap sadar maupun tidak sadar. Berdasarkan definisi di atas dapat disimpulkan bahwa penggerak (yang menyebabkan perilaku siswa) untuk mencapai tujuan belajar adalah motivasi belajar.

Hansen dalam Susanto (2013) Minat belajar siswa berkaitan dengan pengaruh kepribadian, motivasi,genetika,ekspresi, konsep diri, dan lingkungan. Sehingga dapat dikatakan minat memiliki hubungan yang erat dengan motivasi.

Slameto (2010) minat adalah kesukaan dan ketertarikan pada sesuatu aktifitas tanpa perlu ada yang meminta. Kartika (2014) minat belajar yaitu perhatian yang menitikberatkan pada pelajaran tertentu dan diikuti dengan keinginan untuk memahami, belajar, dan menguji melalui partisipasi aktif dalam pembelajaran. Jadi dapat dikatakan bahwa belajar dengan perasaan senang dan selama proses tersebut siswa memberi perhatian lebih sehingga mempermudah pembelajaran disebut minat belajar.

Menurut Ramlah, Firmansyah \& Zubair (2015) prestasi belajar merupakan pencapaian yang muncul pada pengetahuan, sikap, keahlian dan disampaikan dalam wujud nilai atau skor dari hasil tes. Rahim (2010) mengatakan bahwa prestasi belajar didapat dari usaha aktif siswa pada saat pembelajaran sehingga terdapat perubahan pengetahuan yang semakin baik bila siswa menguasai materi. Oleh karena itu prestasi belajar merupakan hasil yang didapatkan siswa pada saat pembelajaran dan dalam kurun waktu tertentu, hasil disini berupa penilaian dari guru kepada siswa untuk menunjukkan penguasaan siswa terhadap materi yang disampaikan.

Karena belum ada penelitian yang membuktikan apakah motivasi dan minat belajar 
berpengaruh terhadap prestasi belajar siswa selama study at home, maka peneliti akan melakukan penelitian mengenai "Pengaruh Motivasi dan Minat Belajar Siswa Terhadap Prestasi Belajar Matematika Selama Study at Home”.

Pendahuluan menguraikan latar belakang permasalahan yang fiselesaikan, isu-isu yang terkait dengan masalah yang diselesaikan, ulasan penelitian yang pernah dilakukan sebelumnya dalam penelitian sebelumnya baik oleh peneliti sendiri atau peneliti lain yang relevan dengan penelitian yang dilakukan. Uraikan perbedaan penelitian yang penulis lakukan dengan penelitian yang sudah dilakukan sebelumnya, atau jika merupakan lanjutan atau pengembanga dari penelitian sebelumnya.

Secara umum, artikel ditulis dengan ukuran kertas A4, jenis huruf Times New Roman dengan batas margin atas $2 \mathrm{~cm}$, bawah $2 \mathrm{~cm}$, kiri $2 \mathrm{~cm}$, dan kanan $2 \mathrm{~cm}$. Penulisan artikel harus dalam format 2 kolom dengan spasi (jarak) antar kolom 1,3 cm.

Bagian ini ditulis dengan huruf Times New Roman ukuran 11 spasi 1 dan dijadikan 2 kolom. Judul pendahuluan ditulis dengan huruf kapital bold.

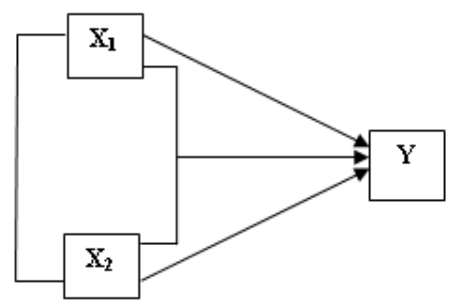

Gambar 1. Desain Penelitian

Pembuatan instrumen sesuai dengan variabel penelitian yang kemudian ditentukan indikatornya dan dibuat beberapa butir pernyataan atau pertanyaan, serta diberi penilaian pada setiap butir soal (Sugiyono, 2010). Pada setiap butir instrumen angket diukur dengan skala rasio yaitu dengan skala Likert. Skala likert dimanfaatkan mengukur sikap, opini sendiri dan opini orang lain atau kelompok tertentu Arikunto (2016).

Pada pengujian hipotesis perlu dilakukan analisis data. Tahapan analisis data meliputi mendiskripsikan data untuk setiap variabel, melakukan uji persyaratan analisis, dan menguji hipotesis.

1. Hipotesis pertama ada pengaruh motivasi belajar terhadap prestasi belajar siswa selama study at home.

2. Hipotesis kedua ada pengaruh minat belajar terhadap prestasi belajar siswa selama study at home.

3. Hipotesis ketiga ada pengaruh motivasi dan minat belajar terhadap prestasi belajar siswa selama study at home.

\section{Metode}

Penelitian ini menggunakan metode kuantitatif dengan menggunakan teknik analisis korelasi dan regresi berganda untuk mengetahui hubungan dan pengaruh antara dua variabel independen dengan variabel dependen. Penelitian ini dilaksanakan di SMAN 16 Surabaya. Jumlah sampel dalam penelitian ini sebanyak 20 siswa yang dipilih dengan teknik random sampling. Pada penelitian ini ada tiga variabel, yaitu dua variabel independen dan satu variabel dependen. Variabel independen meliputi motivasi belajar $\left(X_{1}\right)$ dan minat belajar $\left(X_{2}\right)$. Kedua variabel independen dikumpulkan melalui angket. Untuk variabel dependen hanya satu, yaitu prestasi belajar matematika siswa $(Y)$ yang diperoleh dari pemberian tes matematika. Sebelum angket dan tes diberikan, terlebih dahulu di analisis instrumennya dengan menggunakan uji validitas dan uji reliabilitas.

Desain penelitian dapat dilihat pada gambar dibawah. 
Tabel 1. Hasil skor angket dan tes

\begin{tabular}{|c|c|c|c|}
\hline Responden & Motivasi & Minat & Prestasi \\
\hline R-1 & 44 & 75 & 60 \\
\hline$R-2$ & 51 & 67 & 70 \\
\hline$R-3$ & 65 & 62 & 80 \\
\hline$R-4$ & 50 & 65 & 60 \\
\hline$R-5$ & 70 & 70 & 55 \\
\hline$R-6$ & 53 & 58 & 40 \\
\hline$R-7$ & 58 & 66 & 65 \\
\hline$R-8$ & 64 & 60 & 45 \\
\hline$R-9$ & 69 & 75 & 70 \\
\hline$R-10$ & 57 & 61 & 60 \\
\hline$R-11$ & 51 & 65 & 65 \\
\hline$R-12$ & 66 & 69 & 100 \\
\hline$R-13$ & 58 & 66 & 65 \\
\hline$R-14$ & 71 & 71 & 80 \\
\hline$R-15$ & 54 & 57 & 65 \\
\hline$R-16$ & 60 & 59 & 55 \\
\hline $\mathrm{R}-17$ & 49 & 58 & 70 \\
\hline$R-18$ & 58 & 66 & 50 \\
\hline$R-19$ & 44 & 43 & 40 \\
\hline$R-20$ & 63 & 55 & 70 \\
\hline$R-21$ & 46 & 43 & 60 \\
\hline$R-22$ & 49 & 42 & 55 \\
\hline$R-23$ & 56 & 51 & 75 \\
\hline$R-24$ & 58 & 62 & 75 \\
\hline$R-25$ & 61 & 64 & 80 \\
\hline$R-26$ & 46 & 57 & 65 \\
\hline $\mathrm{R}-27$ & 62 & 57 & 80 \\
\hline$R-28$ & 50 & 50 & 55 \\
\hline$R-29$ & 47 & 48 & 45 \\
\hline
\end{tabular}

A. Distribusi Frekuensi

Distribusi frekuensi berisi deskripsi data pada setiap variabel, termasuk standar deviasi, modus, mean, dan median.

1. Motivasi belajar

Angket motivasi belajar berjumlah 20 butir, dan setiap butir angket memiliki 4 alternatif jawaban yaitu 1,2,3,4. Untuk angket motivasi nilai terendah yaitu 20 dan nilai tertinggi yaitu 80 .

Berdasarkan Tabel 1 yang diperoleh dari responden nilai terendah 44 dan nilai tertinggi 71 , untuk perhitungan statistik dengan menggunakan program diperoleh rata - rata (Mean) sebesar 56,21; modus sebesar 58; median sebesar 57; standar deviasi sebesar 7,97.

Tabel 2. Distribusi Frekuensi Motivasi Belajar Siswa

\begin{tabular}{|c|c|c|c|c|c|}
\hline & & Frequency & Percent & Valid Percent & $\begin{array}{c}\text { Cumulative } \\
\text { Percent }\end{array}$ \\
\hline \multirow[t]{7}{*}{ Valid } & $44-48$ & 5 & 17,2 & 17,2 & 17,2 \\
\hline & $49-53$ & 7 & 24,1 & 24,1 & 41,4 \\
\hline & $54-58$ & 7 & 24,1 & 24,1 & 65,5 \\
\hline & $59-63$ & 4 & 13,8 & 13,8 & 79,3 \\
\hline & $64-68$ & 3 & 10,3 & 10,3 & 89,7 \\
\hline & $69-73$ & 3 & 10,3 & 10,3 & 100,0 \\
\hline & Total & 29 & 100,0 & 100,0 & \\
\hline
\end{tabular}

Seperti terlihat pada Tabel 2 di atas, nilai yg memiliki frekuensi tertinggi terletak pada interval 48-53 dan 54-58.Siswa yang mempunyai nilai berada dibawah rata rata $(56,21)$ sebanyak 14 siswa dan yang mempunyai nilai di atas rata-rata sebanyak 15 siswa. Disimpulkan sebagian nilai motivasi belajar siswa SMAN 16 Surabaya berada di atas rata - rata.
Angket motivasi belajar berjumlah 20 butir, dan setiap butir angket memiliki 4 alternatif jawaban yaitu 1,2,3,4. Untuk angket minat nilai terendah yaitu 20 dan nilai tertinggi yaitu 80 .

Berdasarkan Tabel 1 yang diperoleh dari responden nilai dari 42-75. Rata - rata (Mean) sebesar 60,07; modus sebesar 57 dan 66; median sebesar 61; standar deviasi sebesar 9,01 .

2. Minat belajar

Tabel 3. Distribusi Frekuensi Minat Belajar Siswa 


\begin{tabular}{|rr|r|r|r|r|}
\multicolumn{7}{|c|}{ interval } \\
\hline & & Frequency & Percent & Valid Percent & $\begin{array}{c}\text { Cumulative } \\
\text { Percent }\end{array}$ \\
\hline Valid & $42-47$ & 3 & 10,3 & 10,3 & 10,3 \\
& $48-53$ & 3 & 10,3 & 10,3 & 20,7 \\
& $54-59$ & 7 & 24,1 & 24,1 & 44,8 \\
& $60-65$ & 7 & 24,1 & 24,1 & 69,0 \\
& $66-71$ & 7 & 24,1 & 24,1 & 93,1 \\
& $72-77$ & 2 & 6,9 & 6,9 & 100,0 \\
& Total & 29 & 100,0 & 100,0 & \\
\hline
\end{tabular}

Seperti terlihat pada Tabel 3 di atas, nilai yg memiliki frekuensi tertinggi terletak pada interval 54-59,60-65, dan 66-71. Siswa yang mempunyai nilai berada dibawah rata - rata sebanyak 14 siswa dan yang mempunyai nilai di atas rata - rata sebanyak 15 siswa. Disimpulkan sebagian nilai minat belajar siswa SMAN 16 Surabaya berada di atas rata - rata.
Tes prestasi belajar terdiri dari 3 soal uraian dengan skor 0-100. Berdasarkan Tabel 1 yang diperoleh dari responden nilai dari 40-100, diperoleh rata-rata (Mean) sebesar 63,97; modus sebesar 65; median sebesar 65; standar deviasi sebesar 13,59. Tabel berikut mencantumkan distribusi frekuensi prestasi belajar.

3. Prestasi belajar

Tabel 4. Distribusi Frekuensi Prestasi Belajar

\begin{tabular}{|c|c|c|c|c|c|}
\hline & & Frequency & Percent & Valid Percent & $\begin{array}{c}\text { Cumulative } \\
\text { Percent }\end{array}$ \\
\hline \multirow[t]{7}{*}{ Valid } & $40-49$ & 4 & 13,8 & 13,8 & 13,8 \\
\hline & $50-59$ & 5 & 17,2 & 17,2 & 31,0 \\
\hline & $60-69$ & 9 & 31,0 & 31,0 & 62,1 \\
\hline & $70-79$ & 6 & 20,7 & 20,7 & 82,8 \\
\hline & $80-89$ & 4 & 13,8 & 13,8 & 96,6 \\
\hline & $100-109$ & 1 & 3,4 & 3,4 & 100,0 \\
\hline & Total & 29 & 100,0 & 100,0 & \\
\hline
\end{tabular}

Dilihat pada Tabel 4 di atas, nilai yg memiliki frekuensi tertinggi terletak pada interval 60-69. Ada 13 siswa dengan nilai di bawah mean, dan 16 siswa dengan nilai di atas mean. Disimpulkan sebagian nilai prestasi belajar siswa SMAN 16 Surabaya di atas rata-rata.
Uji normalitas motivasi belajar menggunakan uji Shapiro Wilk menghasilkan nilai $\alpha$ sebesar 0,31 yang menunjukkan bahwa data mengikuti distribusi normal. Hipotesis nol dari uji Saphiro Wilk (yang menyatakan bahwa data mengikuti distribusi normal) gagal ditolak. Sehingga dikatakan data berdistribusi normal.

\section{B. Uji Normalitas}

Tabel 5. Uji Normalitas Motivasi Belajar

\begin{tabular}{|c|r|r|r|r|r|r|}
\hline \multicolumn{1}{|c|}{ Tests of Normality } \\
\cline { 2 - 8 } & \multicolumn{3}{|c|}{ Kolmogorov-Smirnov ${ }^{\text {a }}$} & \multicolumn{3}{c|}{ Shapiro-Wilk } \\
\cline { 2 - 7 } & Statistic & \multicolumn{1}{c|}{ df } & \multicolumn{1}{c|}{ Sig. } & Statistic & df & Sig. \\
\hline motivasi belajar &, 123 & 29 &, $200^{*}$ &, 959 & 29 &, 310 \\
\hline
\end{tabular}

Dari Tabel 6 menghasilkan nilai $\alpha$ sebesar 0,28 yang menunjukkan bahwa data mengikuti distribusi normal. Hipotesis nol dari uji Saphiro

Wilk (yang menyatakan bahwa data mengikuti distribusi normal) gagal ditolak. Sehingga dikatakan data berdistribusi normal.

Tabel 6. Uji Normalitas Minat Belajar

Tests of Normality

\begin{tabular}{|c|r|r|r|r|r|r|}
\hline & \multicolumn{3}{|c|}{ Kolmogorov-Smirnov $^{\mathrm{a}}$} & \multicolumn{3}{c|}{ Shapiro-Wilk } \\
\cline { 2 - 7 } & Statistic & \multicolumn{1}{|c|}{$\mathrm{df}$} & \multicolumn{1}{c|}{ Sig. } & Statistic & \multicolumn{1}{c|}{ df } & \multicolumn{1}{c|}{ Sig. } \\
\hline minat belajar &, 125 & 29 &, $200^{*}$ &, 957 & 29 &, 280 \\
\hline
\end{tabular}

Uji normalitas prestasi belajar menggunakan uji Shapiro Wilk menghasilkan nilai $\alpha$ sebesar 0,45 yang menunjukkan bahwa data mengikuti distribusi normal. Hipotesis nol dari uji Saphiro Wilk (yang menyatakan bahwa data mengikuti distribusi normal) gagal ditolak. Sehingga dikatakan data berdistribusi normal. 
Tabel 7. Uji Normalitas Prestasi Belajar

Tests of Normality

\begin{tabular}{|l|r|r|r|r|r|r|}
\hline & \multicolumn{3}{|c|}{ Kolmogorov-Smirnov ${ }^{\text {a }}$} & \multicolumn{3}{c|}{ Shapiro-Wilk } \\
\cline { 2 - 7 } & Statistic & \multicolumn{1}{c|}{ df } & \multicolumn{1}{c|}{ Sig. } & Statistic & \multicolumn{1}{c|}{ df } & \multicolumn{1}{c|}{ Sig. } \\
\hline prestasi belajar &, 090 & 29 &, $200^{*}$ &, 966 & 29 &, 453 \\
\hline
\end{tabular}

C. Uji Linearitas

Taraf signifikansi pengujian $(\alpha)$ yang dihasilkan oleh Deviation from Linearity pada
Tabel 8 sebesar $0,135>0,05$ sehingga disimpulkan ada hubungan linear antara kedua variabel.

Tabel 8. Uji Linearitas Motivasi Belajar dan Prestasi Belajar

\begin{tabular}{|c|c|c|c|c|c|c|c|}
\hline \multicolumn{8}{|c|}{ ANOVA Table } \\
\hline & & & $\begin{array}{l}\text { Sum of } \\
\text { Squares }\end{array}$ & df & Mean Square & $\mathrm{F}$ & Sig. \\
\hline \multirow{5}{*}{$\begin{array}{l}\text { prestasi belajar" } \\
\text { motivasi belajar }\end{array}$} & \multirow{3}{*}{ Between Groups } & (Combined) & 4500,216 & 20 & 225,011 & 2,692 & .077 \\
\hline & & Linearity & 1088,094 & 1 & 1088,094 & 13,016 & .007 \\
\hline & & Deviation from Linearity & 3412,121 & 19 & 179,585 & 2,148 &, 135 \\
\hline & \multicolumn{2}{|l|}{ Within Groups } & 6687750 & 8 & 83,594 & & \\
\hline & \multicolumn{2}{|l|}{ Total } & 5168.966 & 28 & & & \\
\hline
\end{tabular}

Taraf signifikansi pengujian $(\alpha)$ yang dihasilkan oleh Deviation from Linearity pada disimpulkan ada hubungan linear antara kedua Tabel 9 sebesar 0,226> 0,05 sehingga variabel.

Tabel 9. Uji Linearitas Minat Belajar dan Prestasi Belajar ANOVA Table

\begin{tabular}{|c|c|c|c|c|c|c|c|}
\hline & & & $\begin{array}{l}\text { Sum of } \\
\text { Squares }\end{array}$ & df & Mean Square & $F$ & Sig. \\
\hline \multirow{5}{*}{$\begin{array}{l}\text { prestasi helajar * minat } \\
\text { belajar }\end{array}$} & \multirow[t]{3}{*}{ Between Groups } & (Combined) & 4143,966 & 19 & 218,103 & 1,915 &, 159 \\
\hline & & Linearity & 775,184 & 1 & 775,184 & 6,806 &, 028 \\
\hline & & Deviation from Linearity & 3368,781 & 18 & 187,155 & 1,643 & 226 \\
\hline & \multicolumn{2}{|l|}{ Within Groups } & 1025,000 & 9 & 113,889 & & \\
\hline & \multicolumn{2}{|l|}{$\overline{\text { Total }}$} & 5168,966 & 28 & & & \\
\hline
\end{tabular}

Tabel 10. Uji Multikolinearitas Coefficients $^{\mathrm{a}}$

\begin{tabular}{|c|c|c|c|c|c|c|c|}
\hline & \multicolumn{2}{|c|}{ Unstandardized Coefficients } & \multirow{2}{*}{$\begin{array}{c}\begin{array}{c}\text { Standardized } \\
\text { Coefficients }\end{array} \\
\text { Beta }\end{array}$} & \multirow[b]{2}{*}{$t$} & \multirow[b]{2}{*}{ Sig. } & \multicolumn{2}{|c|}{ Collinearity Statistics } \\
\hline Model & $B$ & Std. Error & & & & Tolerance & VIF \\
\hline (Constant) & 12,027 & 18,393 & & .654 &, 519 & & \\
\hline motivasi belajar &, 601 & 344 &, 353 & 1,748 &, 092 &, 719 & 1,391 \\
\hline minat belajar & 302 & .304 & 200 & 993 & 330 & 719 & 1,391 \\
\hline
\end{tabular}

D. Uji Multikolinearitas

Nilai Tolerance menurut Tabel 10 diperoleh $0,719>0,10$ dan nilai VIF tabel 1,391 < 10,00. Yang berarti tidak terdapat multikolinearitas pada model regresi, sehingga tidak terdapat hubungan pada kedua variabel independen..

E. Uji Hipotesis

Penelitian ini akan diuji tiga hipotesis yaitu pengaruh motivasi belajar terhadap prestasi belajar selama study at home, pengaruh minat belajar terhadap prestasi belajar selama study at home, dan pengaruh motivasi dan minat belajar terhadap prestasi belajar selama study at home.

\section{Pengaruh Motivasi Belajar (X1) terhadap Prestasi Belajar (Y) selama study at home}

Tabel 11. Uji Hipotesis Motivasi belajar 
Coefficients $^{\mathrm{a}}$

\begin{tabular}{|c|c|c|c|c|c|c|}
\hline \multirow[b]{2}{*}{ Model } & & \multicolumn{2}{|c|}{ Unstandardized Coefficients } & \multirow{2}{*}{$\begin{array}{c}\begin{array}{c}\text { Standardized } \\
\text { Coefficients }\end{array} \\
\text { Beta }\end{array}$} & \multirow[b]{2}{*}{$t$} & \multirow[b]{2}{*}{ Sig. } \\
\hline & & $B$ & Std. Error & & & \\
\hline 1 & (Constant) & 20,005 & 16,543 & & 1,209 & 237 \\
\hline & motivasi belajar & .782 & 291 & .459 & 2,683 & .012 \\
\hline
\end{tabular}

Dilihat dari Tabel 11 rumus persamaan regresi linear sederhana yaitu $Y=a+$ $b X$ dengan nilai koefisien regresi sebagai berikut.

a merupakan angka konstanta dengan nilai sebesar 20,005 yang berarti prestasi belajar akan bernilai 20,005 bila tidak ada motivasi belajar. $b$ yaitu angka koefisien regresi dengan nilai sebesar yang memiliki arti setiap penambahan $1 \%$ tingkat motivasi akan meningkat 0,782 prestasi belajar siswa. Dengan demikian persamaan regresinya $Y=20,005+0,782 X$.

Untuk uji hipotesis dengan $H_{0}=$ tidak ada pengaruh motivasi belajar terhadap prestasi belajar selama study at home

$H_{1}=$ ada pengaruh motivasi belajar terhadap prestasi belajar selama study at home.

Uji hipotesis yang pertama dilakukan dengan membandingkan nilai signifikansi pengujian $(\alpha)$ dengan probabilitas 0,05 , dilihat dari Tabel 11 diperoleh nilai signifikansi pengujian $0,012<0,05$ dan membandingkan t-hitung dengan t-tabel, dilihat dari Tabel 11 nilai t-tabel $2,051<\mathrm{t}$ hitung 2,683. Jadi dari perbandingan nilai signifikansi pengujian dan nilai $t$ disimpulkan $H_{0}$ ditolak dan $H_{1}$ diterima yang memiliki arti "Motivasi Belajar

berpengaruh terhadap prestasi belajar selama study at home". Hasil tersebut sesuai dengan peneliti sebelumnya yang memiliki pengaruh signifikan motivasi belajar pada prestasi belajar siswa (Kurniawan dan Wutsqa, 2014) yang berdasarkan hasil regresi ganda setiap penambahan $1 \%$ motivasi belajar siswa akan meningkat 0,298 prestasi belajar siswa. Pada (Kurniawan dan Wutsqa, 2014) disebutkan juga motivasi belajar memiliki pengaruh pada prestasi belajar dengan didukungnya lembar angket yang dijawab oleh siswa menjawab sering dan konsisten pada pernyataan - pernyataan yang bersifat positif dan negatif pada angket motivasi belajar. Ada beberapa aspek yang merefleksikan variabel motivasi sehingga menunjukkan besarnya pengaruh motivasi belajar pada prestasi belajar siswa. Ada beberapa perbedaan penelitian ini dengan penelitian Kurniawan dan Wutsqa yaitu populasi pada penelitian ini siswa SMA sedangkan penelitian Kurniawan dan Wutsqa menggunakan populasi siswa SMP. Pada penelitian ini juga peneliti mengambil data secara online karena siswa sedang melaksanakan pembelajaran jarak jauh (study at home)

\section{Pengaruh Minat Belajar (X2) terhadap} Prestasi Belajar (Y) selama study at home

Tabel 12. Uji Hipotesis Minat Belajar Coefficients $^{\star}$

\begin{tabular}{|c|c|c|c|c|c|c|}
\hline \multirow[b]{2}{*}{ Model } & & \multicolumn{2}{|c|}{ Unstandardized Coefficients } & \multirow{2}{*}{\begin{tabular}{|c|}
$\begin{array}{c}\text { Standardized } \\
\text { Coefficients }\end{array}$ \\
Beta \\
\end{tabular}} & \multirow[b]{2}{*}{$t$} & \multirow[b]{2}{*}{ Sig. } \\
\hline & & $B$ & Std. Error & & & \\
\hline 1 & (Constant) & 28,877 & 16,250 & & 1,777 & 087, \\
\hline & minat belajar & .584 & 268 &, 387 & 2,183 &, 038 \\
\hline
\end{tabular}

Dilihat dari Tabel 12 rumus persamaan regresi linear sederhana yaitu $Y=a+$ $b X$ dengan nilai koefisien regresi sebagai berikut.

$a$ yaitu angka konstan dari Unstandardized Coefficients dengan nilai 28,877 yang berarti apabila tidak ada motivasi belajar maka nilai konsisten prestasi belajar sebesar 28,877. $b$ bernilai 0,584 yang merupakan koefisien regresi. Jadi setiap bertambah $1 \%$ tingkat minat belajar maka akan meningkat 0,584 prestasi belajar. Dengan demikian persamaan regresinya $Y=28,877+0,584 X$.

Untuk uji hipotesis berfungsi untuk mengetahui koefisien regresi tersebut signifikan atau tidak. Dengan $H_{0}=$ tidak ada pengaruh minat belajar terhadap prestasi belajar selama study at home 
$H_{1}=$ ada pengaruh minat belajar terhadap prestasi belajar selama study at home.

Uji hipotesis yang pertama dilakukan dengan membandingkan nilai signifikansi pengujian dengan probabilitas 0,05 , dilihat dari tabel diatas nilai signifikansi pengujian $0,038<0,05$ dan uji hipotesis yang kedua membandingkan t-hitung dan t-tabel, dilihat dari gambar diatas nilai t-tabel 2,051 $<$ t-hitung 2,183. Jadi dari perbandingan nilai signifikansi pengujian dan nilai $\mathrm{t}$ didapatkan $H_{0}$ ditolak dan $H_{1}$ diterima. Dapat disimpulkan bahwa "Minat Belajar berpengaruh terhadap prestasi belajar

selama study at home". Hasil ini sesuai pada penelitian Siagian (2015) yang mengatakan bila minat belajar berpengaruh pada prestasi belajar matematika di SMK PGRI 16 Cipayung Jakarta Timur. Perbedaan yang mendasari penelitian ini dengan penelitian Siagian yaitu target populasi, untuk penelitian ini populasinya siswa SMAN 16 Surabaya yang sedang belajar dirumah selama study at home.

\section{Pengaruh Motivasi Belajar (X1) dan Minat Belajar (X2) terhadap Prestasi Belajar (Y) selama study at home}

Tabel 13. Uji Hipotesis Variabel Motivasi Belajar dan Minat Belajar Coefficients $^{\mathrm{a}}$

\begin{tabular}{|c|c|c|c|c|c|c|}
\hline \multirow[b]{2}{*}{ Mode } & & \multicolumn{2}{|c|}{ Unstandardized Coefficients } & \multirow{2}{*}{$\begin{array}{c}\begin{array}{c}\text { Standardized } \\
\text { Coefficients }\end{array} \\
\text { Beta }\end{array}$} & \multirow[b]{2}{*}{$t$} & \multirow[b]{2}{*}{ Sig. } \\
\hline & & $B$ & Std. Error & & & \\
\hline \multirow[t]{3}{*}{1} & (Constant) & 12,027 & 18,393 & &, 654 & 519 \\
\hline & motivasi belajar &, 601 &, 344 &, 353 & 1,748 &, 092 \\
\hline & minat belajar & 302 & 304 & 200 & 993 & 330 \\
\hline
\end{tabular}

Dilihat dari Tabel 13 rumus persamaan regresi linear berganda yaitu $Y=a+$ $b_{1} X_{1}+b_{2} X_{2}$ dengan nilai koefisien regresi sebagai berikut.

$a$ yaitu angka konstan dari Unstandardized Coefficients dengan nilai $12,027, b$ yang memiliki nilai 0,601 merupakan koefisien regresi motivasi belajar dan angka koefisien regresi minat belajar sebesar 0,302 . Dengan demikian persamaan regresinya $Y=$ $12,027+0,601 X_{1}+0,302 X_{2}$.

Dapat dilihat uji hipotesis berikut.

Tabel 14. Hasil Uji F Menggunakan SPSS ANOVA $^{\text {a }}$

\begin{tabular}{|c|c|c|c|c|c|c|}
\hline \multicolumn{2}{|c|}{ Model } & $\begin{array}{l}\text { Sum of } \\
\text { Squares }\end{array}$ & df & Mean Square & $\mathrm{F}$ & Sig. \\
\hline \multirow[t]{3}{*}{1} & Regression & 1237,276 & 2 & 618,638 & 4,091 &, $029^{\mathrm{b}}$ \\
\hline & Residual & 3931,689 & 26 & 151,219 & & \\
\hline & Total & 5168,966 & 28 & & & \\
\hline
\end{tabular}

Pada pengujian hipotesis kali ini menggunakan uji $\mathrm{F}$ dengan hipotesis adanya pengaruh motivasi belajar dan minat belajar terhadap prestasi belajar selama study at home. Ada dua cara untuk menguji hipotesis tersebut, bisa dengan membandingkan nilai signifikansi pengujian atau mencari nilai F-hitung dibanding nilai F-tabel. Berdasarkan Tabel 14 didapat nilai signifikansi $0,029<0,05$ yang bermakna hipotesis diterima, membandingkan nilai F-hitung yang terlihat pada Tabel 14 4,091 sedangkan untuk nilai F-tabel didapatkan 3,35 yang berarti F-hitung > F-tabel dan hipotesis diterima. Dari dua perbandingan diatas dapat disimpulkan hipotesis sama - sama diterima ada "Pengaruh Motivasi dan Minat belajar terhadap Prestasi belajar selama study at home". Penelitian ini sejalan dengan (Heriyati, 2017) yang memiliki Fhitung $5,567>$ F-tabel 3,15 berarti menunjukkan adanya pengaruh minat dan motivasi belajar terhadap prestasi belajar matematika. Penelitian Heriyati (2017) dan penelitian pada artikel ini membuktikan bahwa kegiatan belajar di sekolah dan di rumah cukup selaras dalam proses perkembangan siswa Hal ini didasari oleh hasil penelitian yang serupa, dimana kedua penelitian menyatakan motivasi dan minat belajar berpengaruh terhadap prestasi belajar selama di sekolah maupun di rumah. Perbedaan yang mendasari pada penelitian ini dengan penelitian Heriyati yaitu target populasi, untuk penelitian ini populasinya siswa SMAN 16 Surabaya yang sedang belajar dirumah selama study at home. Penelitian Trisnowali (2017) juga mengatakan bahwa motivasi belajar matematika, minat belajar matematika memberikan pengaruh positif terhadap hasil belajar matematika siswa kelas $\mathrm{X}$ SMAN 2 Watampone. Perbedaannya hanya 
saja pada penelitian ini proses pembelajaran dilakukan dirumah.

\section{Simpulan}

Berdasarkan pengujian hipotesis pada penelitian maka hasil penelitian dengan judul Pengaruh Motivasi dan Minat Belajar Terhadap Prestasi Belajar Siswa Selama Study at Home dengan populasi siswa SMAN 16 Surabaya diperoleh kesimpulan.

1. Ada pengaruh motivasi belajar terhadap prestasi belajar siswa selama study at home dengan nilai t-hitung sebesar 2,683 lebih besar dari nilai t-tabel 2,051

2. Ada pengaruh minat belajar terhadap prestasi belajar siswa selama study at home dengan nilai t-hitung sebesar 2,183 lebih besar dari nilai ttabel 2,051

3. Ada pengaruh motivasi dan minat belajar terhadap prestasi belajar siswa selama study at home dengan nilai F-hitung sebesar 4,091 lebih besar dari F-tabel 3,35

\section{Daftar Pustaka}

Arikunto, S. (2016). Prosedur Penelitian Suatu Pendekatan Praktik. Jakarta: Rineka Cipta.

Badaruddin, A. 2015. Peningkatan Motivasi Belajar Siswa melalui Konseling Klasikal. CV Abe Kreatifindo

Dahlan, M. S. (2009). Statistik untuk kedokteran dan kesehatan: deskriptif, bivariat dan multivariat, dilengkapi dengan menggunakan SPSS. Jakarta: Salemba Medika.

DIKDAS,GTK. 2020. Pembelajaran Jarak Jauh Selama Masa Pandemi. http://pgdikdas.kemdikbud.go.id/readnews/pembelajaran-jarak-jauh-selama-masapandemi (diakses tanggal 18 September 2020).

Ghozali, I. 2016. Aplikasi Analisis Multivariete Dengan Program IBM SPSS 23. Edisi 8. Semarang: Badan Penerbit Universitas Diponegoro.

Heriyati, H. 2017. Pengaruh Minat dan Motivasi Belajar Terhadap Prestasi Belajar Matematika. Formatif: Jurnal Ilmiah Pendidikan MIPA, Vol 7(1): Hal 22-32

Kartika, H. (2014). Pembelajaran Matematika Berbantuan Software Matlab sebagai Upaya Meningkatkan Kemampuan Komunikasi Matematis dan Minat Belajar Siswa SMA. JUDIKA (Jurnal Pendidikan Unsika), 2(1).

Kurniadi. 2020. Menyiapkan Pendidikan Menuju Normal Baru. pendidikan-menuju-normal-baru/ (diakses tanggal 18 September 2020)

Kurniawan, D., \& Wustqa, D. U. (2014). Pengaruh perhatian orangtua, motivasi belajar, dan lingkungan sosial terhadap prestasi belajar matematika siswa SMP. Jurnal riset pendidikan matematika, 1(2), 176-187.

Ni'mah, F. I. (2016). Manajemen Pembelajaran Jarak Jauh (Distance Learning) Pada Homeschooling "Sekolah Dolan". Manajemen Pendidikan, 25(1), 112-119

Noesgaard, S. S., \& Ørngreen, R. (2015). The effectiveness of e-learning: An explorative and integrative review of the definitions, methodologies and factors that promote eLearning effectiveness. Electronic Journal of E-Learning, 13(4), 278-290

Rahim, U. (2010). Meningkatkan Prestasi Belajar Matematika Siswa Pada Pokok Bahasan Faktorisasi Suku Aljabar Melalui Pendekatan Struktural Think Pair Share (TPS) Siswa Kelas VIII2 SMPN 4 Kendari. Jurnal MIPMIPA, 9(1).

Ramlah, R., Firmansyah, D., \& Zubair, H.2015. Pengaruh Gaya Belajar dan Keaktifan Siswa Terhadap Prestasi Belajar Matematika (Survey Pada SMP Negeri di Kecamatan Klari Kabupaten Karawang). Majalah Ilmiah SOLUSI, 1(03).

Santoso, S. (2014). Panduan Lengkap SPSS versi 20 edisi revisi. Jakarta: PT. Elex Media Komputindo.

Siagian, R.E.F., 2015. Pengaruh minat dan kebiasaan belajar siswa terhadap prestasi belajar matematika. Formatif: Jurnal Ilmiah Pendidikan MIPA, 2(2).

Siregar, S. (2015). Statistika terapan untuk perguruan tinggi. Jakarta: Prenadamedia Group.

Slameto. 2010. Belajar dan Faktor-Faktor yang Mempengaruhi. Jakarta: Rineka Cipta

Sofyan, H., \& Uno, H. B. 2012. Teori Motivasi dan Penerapannya dalam penelitian. Yogyakarta: UNY Press

Sugiyono. 2010. Metode Penelitian Pendidikan Pendekatan Kuantitatif, kualitatif, dan R\&D. Bandung: Alfabeta.

Susanto, Ahmad. 2013. Teori Belajar dan Pembelajaran di Sekolah Dasar. Jakarta: Kencana Prenadamedia Group.

Trisnowali, A. (2017). Pengaruh Motivasi Berprestasi, Minat Belajar Matematika, Dan Sikap Belajar Matematika Terhadap Hasil Belajar Matematika Pada Siswa Sman 2 Watampone. Jurnal Matematika dan Pembelajaran, 5(2), 259-277. 
Widiyanto, B. (2010). Populasi dan Sampel Penelitian. Jakarta: Pusat Perbukuan Kementerian Pendidikan Nasional 